\title{
Doktorat - źródło niepewności czy strategia jej niwelowania?
}

Aleksandra Leyk | Wydział Filologii i Socjologii, Uniwersytet Warszawski

Słowa kluczowe: studia doktoranckie, prekaryzacja, niepewność pracy, praca na rzecz pracy, narracyjne wywiady biograficzne

Keywords: PhD studies, precariousness, work and labour insecurity, work for labour, narrative biographical intereviews

\section{Streszczenie}

Trend ograniczania zatrudnienia na uczelniach z równoległym wzrostem liczby doktorantów znacząco ograniczył ich perspektywy zatrudnienia. Jednocześnie pozaakademicki rynek pracy, na którym wielu z nich próbuje się zakotwiczyć, nie sprzyja stabilizacji.

W artykule przybliżam doświadczenia doktorantów związane z godzeniem życia naukowego, zawodowego i osobistego w kontekście niepewności akademickiego i pozaakademickiego rynku pracy. Podejmuję próbę analizy wzajemnych uwarunkowań między tymi doświadczeniami a motywacjami oraz strategiami działania badanych.

Doświadczenia doktorantów traktuję jako przykład problemów i napięć związanych z pracą w nowym kapitalizmie, odnosząc się m.in. do pojęć proponowanych przez Guya Standinga (niepewność pracy, praca na rzecz pracy) oraz Luca Boltańskiego i Eve Chiapello (aktywność jako cecha wzorcowego człowieka nowego kapitalizmu).

Podstawą empiryczną artykułu są biograficzne wywiady narracyjne przeprowadzone z doktorantami kierunków humanistycznych i społecznych oraz kierunków technicznych na uniwersytecie.

\section{PHD Thesis - the source of precariousness or a strategy to limit it? Summary}

The trend of limiting employment at universities with a parallel increase in the number of doctoral students significantly reduced their employment prospects. At the same time, the non-academic labour market, where many of them try to anchor, does not offer much of stability.

In the article I focus on the ways PhD students cope with the challenge of balancing academic activities with work and personal life in the context of uncertainty and insecurity of the academic and non-academic labour markets. I attempt to analyse the mutual conditioning between these experiences and the motivations and strategies of the interviewees. I treat the experience of PhD students as an example of problems and tensions related to work in the new capitalism, referring to the concepts proposed by Guy Standing 
(work and labour insecurity, work for labour) and Luc Boltański and Eve Chiapello (activity as a key feature of a new capitalist man).

The empirical basis of the article is biographical narrative interviews with PhD students of humanities and social sciences as well as technical faculties at the university.

\section{Wstęp}

Przemiany w szkolnictwie wyższym w istotny sposób odbijają się na pracy naukowców. W artykule pragnę przyjrzeć się sytuacji grupy, która znajduje się na peryferiach akademickiego rynku pracy, choć jednocześnie stanowi źródło przyszłych kadr naukowych, to jest doktorantom. W 2016 r. szeroko komentowano raport Nie zostaje mi czasu na pracę naukowa (Kowzan i in. 2016), poświęcony problemom pracowników uczelni ze stopniem doktora. Tytułowy brak czasu na pracę naukową, niskie dochody i konieczność dywersyfikowania ich źródeł, obarczenie obowiązkami biurokratycznymi, czasowość umów - to problemy, które pojawiają się również w doświadczeniach doktorantów, jednak sytuacja tych dwóch grup jest diametralnie odmienna z tego zasadniczego względu, iż doktoranci rzadko bywają pracownikami uczelni. Doświadczają więc większej niestabilności i niepewności związanej z pracą naukową.

Niepewność zaczyna się od samego statusu doktoranta - ni to studenta, ni to pracownika. Mimo ustawowej próby jego regulacji w 2005 r. ${ }^{1}$ pozostaje on niejasny. Od studentów niższych stopni odróżniają go niektóre przywileje, ale także obowiązki, które upodobniają go do pracowników (asystentów) ${ }^{2}$. Pozbawieni są jednak przywilejów wynikających ze stosunku pracy, takich jak choćby płatny urlop wypoczynkowy czy macierzyński.

Niepewność wynika także z faktu, iż doktoranci mają coraz bardziej znikome szanse na zatrudnienie na uczelni. W latach 2006-2017 liczba zatrudnionych pełnoetatowo nauczycieli akademickich spadła z 96747 do $91603^{3}$ (GUS 2007; 2017), a więc o ok. 5 tys., w tym asystentów o ok. 4 tys., a adiunktów ze stopniem doktora o ok. 3 tys. ${ }^{4}$ Jednocześnie zwiększyła się konkurencja, jako że o ile w początku lat 2000 liczba doktorantów wahała się w okolicach 30 tys. (GUS 2007: 27), to od 2014 r. przekracza 43 tys. (GUS 2017: 39). W latach 2005-2016 każdego roku na rynek pracy przybywało ok. 5-6 tys. nowo mianowanych doktorów (GUS 2017: 430). Z perspektywy indywidualnych losów niski poziom zatrudnienia jest z pewnością istotną zmienną, jednak jeszcze ważniejszy jest jego szybki spadek, ponieważ oznacza on, że realia zmieniały się znacząco w okresie od podjęcia decyzji o studiach doktoranckich do ich ukończenia,

\footnotetext{
${ }^{1}$ Ustawa z dnia 27 lipca 2005 r. - Prawo o szkolnictwie wyższym.

2 Analizę statusu doktoranta w świetle prawodawstwa oraz praktyk uczelni przedstawiano w publikacji (Szwiedziak-Bork 2014).

${ }^{3}$ Zatrudnienie niepełnoetatowe pozostaje nieznaczące. W 2017 r. stanowiło ok 3,5\%, aczkolwiek warto zauważyć, że w grupie asystentów jest wyższe: 5,5\%. Dalej przytaczane dane dotyczą zatrudnionych pełnoetatowo.

${ }^{4}$ Z ok. 35 tys. do 32 tys. (GUS 2007, GUS 2017).
} 
a opierając się na doświadczeniach starszych pokoleń, doktoranci mogli przewidywać większe szanse na zatrudnienie.

Kariera poza uczelnią także wydaje się trudno osiągalna. W całym sektorze badawczo-rozwojowym w latach 2005-2016 zatrudnienie osób ze stopniem doktora zwiększyło się o ok. 5,5 tys. ${ }^{5}$, czyli mniej więcej tyle, ilu doktorów pojawia się na rynku jednego roku. Za to pracodawcy spoza tego sektora nie wykazują istotnego zainteresowania zatrudnianiem osób ze stopniem naukowym doktora (NIK 2015: 7).

Brak danych na temat losów absolwentów uniemożliwia opisanie sytuacji doktorantów na pozaakademickim rynku pracy. Warto jednak odnotować, że Polska znajduje się $w$ awangardzie stosowania umów czasowych. Według danych Eurostatu w roku 2016 aż 27,5\% pracujących Polaków było zatrudnionych na umowach czasowych, natomiast $w$ będącej przedmiotem analizy grupie wiekowej $25-34$ było to $35 \%$ pracujących. Z kolei praca w niepełnym wymiarze, która akurat w przypadku doktorantów mogłaby być pożądana, dotyczy tylko 6,5\% pracującej populacji, z czego zaledwie $9 \%$ respondentów wskazało jako jej powód edukację lub szkolenie, co daje sumę ok. 50 tys. osób. Oznacza to, że elastyczność przejawia się więc w formach z perspektywy doktorantów niekorzystnych - 1/3 młodych zatrudniona jest na umowach czasowych, niewielu ma za to możliwość pracy w niepełnym wymiarze zatrudnienia.

Sytuacja finansowa doktorantów stanowi kolejny czynnik niesprzyjający stabilności. Doktorat z pewnością nie jest sposobem na zapewnienie sobie samodzielności ekonomicznej. Stypendium doktoranckie ustawowo może wynosić zaledwie $60 \%$ minimalnego wynagrodzenia przewidzianego dla asystenta ${ }^{6}$ (niecałe 1500 zł na przestrzeni ostatnich lat). W roku 2016/2017 stypendia doktoranckie pobierało $22 \%$ studentów szkół wyższych ${ }^{7}$, w tym 15\% z dotacji projakościowej, a na uniwersytetach było to $14 \%$ (liczba pobierających stypendia doktoranckie i z dotacji projakościowej była prawie taka sama) (GUS 2017). Zakładając, że stypendia z dotacji projakościowej otrzymują przede wszystkich osoby otrzymujące stypendium doktoranckie ${ }^{8}$, oznacza to, że zaledwie $14 \%$ doktorantów uniwersytetów otrzymywało ok. 2300 zł, a pozostali nie otrzymywali żadnego liczącego się stypendium. Z kolei z badań kwestionariuszowych wynika, że w naukach humanistycznych i społecznych stypendium doktoranckie pobierało

5 Z 40897 do 46281 (GUS 2017: 424).

${ }^{6}$ Wysokość stypendium pozostaje w gestii rektora i może być wyższa, a praktyki jednostek w tym zakresie są zróżnicowane, w wielu jednostkach pozostaje jednak na poziomie minimalnym. Nie zmienia to też faktu, że status doktoranta jest z ustawowego założenia niższy niż status asystenta, który ma zapewnione wyższe wynagrodzenie oraz przywileje wynikające ze stosunku pracy. To samo dotyczy stypendium z dotacji projakościowej wynoszącego min. 800 zł. Na przykład na Uniwersytecie Warszawskim wynosiło ono w ostatnich latach $1000 \mathrm{zł}$, podczas gdy stypendium doktoranckie utrzymywane jest na minimalnym poziomie.

${ }^{7}$ W populacji doktorantów szkół publicznych i studiów stacjonarnych.

${ }^{8}$ Możliwe było otrzymanie stypendium z dotacji projakościowej mimo braku stypendium doktoranckiego. Było to raczej rzadkie, ale jest możliwe, że część ze wspomnianych 14\% zarabiała mniej na rzecz niewliczonych w tę pulę osób. 
znacznie mniej studentów, bo odpowiednio 5,1\% i 5\% (Bień 2016: 253) ${ }^{9}$. Należy także podkreślić, iż nie wszystkie stypendia dostępne są na pierwszym roku. Na początku studiów trudno też o własny grant, a jeśli już zostanie on zdobyty, to nie może być głównym źródłem utrzymania. O ile w 2012 r. Rada Naukowa NCN rekomendowała maksymalną wysokość wynagrodzenie brutto dla doktoranta na poziomie 3000 zł, to już w 2015 r. pojawił się komunikat, iż w projektach własnych doktoranci mogą przeznaczyć na swoje wynagrodzenie maksimum 1000 zł brutto ${ }^{10}$. Rozpoczęcie studiów doktoranckich wymaga więc posiadania innych źródeł utrzymania i wiąże się z niepewnością co do tego, jaki dochód będzie można uzyskać w kolejnych latach studiów.

Istotnym kontekstem funkcjonowania doktorantów obok kwestii systemu finansowania nauki, regulacji stypendialnych i grantowych są m.in. organizacja studiów doktoranckich, oferty kształcenia i obowiązki dydaktyczne, a także jakość współpracy na uczelniach, poziom wsparcia czy zakres i sposób egzekwowania prac świadczonych przez doktorantów na rzecz uczelni. Omówienie wpływu tych zagadnień na doktorantów znajduje się w licznych dokumentach o charakterze eksperckim lub publicystycznym, których autorzy wskazują na trudności i problemy niesprzyjające rozwojowi naukowemu i pracy doktorantów (zob. m.in.: Kraśniewski 2009; Dokowicz i in. 2014; Malanowska 2013; Michalak 2013, Sobkowiak 2015). Wartym wyodrębnienia ze względu na podłoże badawcze oraz swoją aktualność jest tekst Studia trzeciego stopnia w polskich uczelniach - funkcjonowanie, diagnoza, rekomendacje (Bień 2016) oparty na szeroko zakrojonych badaniach ilościowych prowadzonych przez Doktoranckie Forum Uniwersytetów Polskich oraz na danych GUS. Obejmuje on problematykę finansowania, jakości kształcenia, dydaktyki, warunków prowadzenia badań oraz samorządności. Z perspektywy analiz niepewności doktorantów szczególnie cenny jest artykuł, w którym odnosząc się do wspomnianych badań oraz regulacji, Dominik Bień przedstawia analizę różnych aspektów bezpieczeństwa związanego z funkcjonowaniem doktorantów na uczelni, zadając pytanie, czy doktoranci to kolejna grupa prekariatu (Bień, tekst niepublikowany). Brak niestety analogicznych analiz dotyczących bezpieczeństwa pracy pozaakademickiej doktorantów.

Celem poniższego artykułu jest próba odpowiedzi na pytanie, w jaki sposób doktoranci odnajdują się w niepewnym kontekście akademickiego i pozaakademickiego rynku pracy oraz jaką rolę w ich biografiach pełni doktorat. Badania przytaczane w niniejszym artykule mają charakter eksploracyjny, dlatego też pozwalają zabrać głos

\footnotetext{
${ }^{9}$ Wprowadzony w 2017 r. art. 195a ustawy Prawo o szkolnictwie wyższym nakazuje wypłacanie stypendium doktoranckiego co najmniej 50\% uczestników studiów w jednostce. Rezultaty tej zmiany nie były jednak jeszcze widoczne w prowadzonych badaniach.

${ }_{10}$ Uzasadnieniem tej rekomendacji było wskazanie, że „zapewnienie wynagrodzenia dla doktoranta jest obowiązkiem jego promotora, który odpowiednie środki finansowe powinien zapewnić w ramach własnego grantu" (https://ncn.gov.pl/aktualnosci/2015-06-17-wyjasnienia-wynagrodzenia-preludium). Zmianie tej nie towarzyszyły jednak żadne zmiany systemowe, które przyczyniłyby się do wzrostu liczby doktorantów otrzymujących zatrudnienie w grantach swych promotorów czy innych pracowników naukowych. Zniknęła więc jedna z możliwości utrzymania się z pracy naukowej.
} 
w dyskusji wychodzący poza własne obserwacje, jednak bez ambicji stawiania wniosków dla całej populacji doktorantów.

Empiryczną podstawą niniejszego tekstu jest 15 narracyjnych wywiadów biograficznych (Schütze 1983; Kaźmierska 1996; Rosenthal 1993) zrealizowanych w latach 20152017. Były one prowadzone $w$ ramach projektu dotyczącego strategii ludzi młodych wobec niepewności na rynku pracy" ${ }^{11}$ co wpłynęło na szczegółowe kryteria doboru rozmówców, a także liczbę wywiadów z doktorantami (jako nie jedynej grupy rozmówców). Wywiady przeprowadzono ze studentami dwóch uniwersytetów w dwóch miastach - 13 z nich doktoryzowało się w obszarze nauk humanistycznych i społecznych, a 2 nauk technicznych ${ }^{12}$. Rozmówcy byli w wieku 25-35 lat i studiowali od roku do pięciu lat. Warunkiem udziału w badaniu był brak zatrudnienia na umowę o pracę na czas nieokreślony. W wywiadach udział wzięła jedna osoba niepracująca i nieposzukująca pracy, poza tym wszyscy rozmówcy pracowali na umowach cywilnoprawnych, czasowych umowach o pracę lub jako samozatrudnieni albo poszukiwali pracy. Rozmówcy zostali poproszeni o opowiedzenie swoich losów edukacyjnych i zawodowych, a następnie poruszano z nimi szczegółowe zagadnienia związane z nauką, pracą, poczuciem bezpieczeństwa, samodzielnością ekonomiczną, łączeniem różnych aktywności życiowych i oceną studiów doktoranckich.

Analizę rozpoczynam od motywacji do podjęcia studiów doktoranckich, by w kolejnej części przyjrzeć się doświadczeniom związanym z godzeniem pracy naukowej, zarobkowej oraz życia prywatnego w trakcie studiów, by na koniec wrócić do zmieniających się pod wpływem tych doświadczeń motywacji. $Z$ analizy wyłaniają się różne strategie „na doktorat", ale i szereg wspólnych im problemów.

11 Projekt został sfinansowany ze środków Narodowego Centrum Nauki przyznanych na podstawie decyzji numer DEC-2013/09/N/HS6/02607.

12 Doborem rozmówców kierowało dążenie do dotarcia do doktorantów, którzy funkcjonują w warunkach większej niż inni niepewności. Dlatego też z badania wykluczono doktorantów z obszarów nauk ścisłych, przyrodniczych, nauk medycznych i o zdrowiu oraz sztuki. Uczelnie medyczne i artystyczne mają najwyższe wskaźniki efektywności kształcenia doktorantów (NIK 2015: 21), a specyfika tych nauk znacząco determinuje przyszłość zawodową absolwentów. Także w przypadku nauk ścisłych i przyrodniczych wskaźnik efektywności kształcenia doktorantów jest wyższy niż w przypadku humanistycznych i społecznych ((NIK 2015: 19). Efektywność kształcenia nie jest oczywiście jednoznacznym wskaźnikiem niepewności rynku pracy. Niemniej jednak wydaje się, że studia doktoranckie z wykluczonych z badania obszarów wymagają większego zaangażowania doktorantów w pracę na uczelni (ze względu na praktyczny wymiar), a tym samym skłaniają jednostki je prowadzące do takiej organizacji studiów, która minimalizuje przypadki łączenia ich z aktywnościami zarobkowymi niezwiązanymi z dziedziną. Wyższy wskaźnik efektywności kształcenia sprzyja tej hipotezie. Wydaje się również, iż dają one lepsze perspektywy kontynuacji kariery w świecie akademickim lub poza nim. Dodatkowym czynnikiem odróżniającym negatywnie nauki humanistyczne i społeczne od pozostałych jest niższy wskaźnik osób pobierających stypendia. Nauki techniczne plasują się pomiędzy zarysowanymi biegunami, dlatego też zdecydowano się na uwzględnienie reprezentantów tych obszarów, ale w marginalnym stopniu.

W badaniu nie uwzględniono doktorantów instytutów naukowych i badawczych, a także studentów studiów niestacjonarnych, głównie ze względu na ich niewielki udział w całej populacji doktorantów: odpowiednio 5,7\% oraz 13\% (obliczenie własne na podstawie GUS 2017: 158) oraz odmienną specyfikę. 


\section{Motywacje do podjęcia studiów doktoranckich: rozwój, kontynuacja, niedosyt}

Z badań Małgorzaty Dąbrowy-Szefler oraz Pawła Sztabińskiego (2008) wynika, iż głównym powodem podjęcia studiów doktoranckich dla ponad połowy badanych w 2005 r. doktorantów ${ }^{13}$ była chęć kontynuowania kształcenia i pogłębiania wiedzy w wybranej dziedzinie. Kilkanaście procent nastawionych było na karierę akademicką, a jedynie 5\% nie było zdecydowanych, co robić po studiach. Wnioski te zdecydowanie podważają stereotypowe postrzegania doktorantów jako ludzi niezdecydowanych, wiecznych studentów uciekających przed dorosłością. $Z$ badań wyłania się także krytyczny obraz możliwości zawodowych doktorantów na akademickim i pozaakademickim rynku pracy, stwierdzony zarówno przez nich, jak i potencjalnych pracodawców. Niestety, powyższe badania opisują rzeczywistość z lat 2005-2007, a więc sprzed znaczących zmian prawnych i demograficznych. Problematykę motywacji, a także częściowo kontekstu funkcjonowania doktorantów, podejmują w nieco bardziej aktualnych badaniach Anna Domaradzka i Anna Walczak (2013), które zaproponowały typologię doktorantów wg ich motywacji do studiowania. Daje ona wgląd w zróżnicowanie motywów oraz niektórych cech kontekstu, w jakim doktoranci funkcjonują, ale nie w ich wzajemne uwarunkowania. Potraktowanie motywacji jako stałej nie pozwala dostrzec, iż może ona być np. formą adaptacji lub racjonalizacji wobec zastanego kontekstu i indywidualnych losów. W prezentowanych w artykule badaniach rozmówcy opisywali swoje pierwotne motywacje, ale także zmieniający się pod wpływem doświadczeń życiowych stosunek do doktoratu, dzięki czemu możliwe jest analizowanie motywów studiowania w relacjach z jego kontekstem.

Wspólną wszystkim rozmówcom motywacją do rozpoczęcia doktoratu była potrzeba rozwoju intelektualnego. Przywoływali oni chęć dalszego uczenia się, spełniania się, realizacji pasji, sprawdzania siebie czy przeżycia ekscytacji:

[chciałam] się w tym spełniać. [Brakowało mi] Nauki. Bardzo. (...) zawsze jest we mnie ta chęć poszerzania horyzontów, chęć poszerzania wiedzy i odkrywania, jakby, siebie na nowo przez to. Wyznaczania sobie celów do których chcę dążyć, sprawdzenia siebie. $[A]^{14}$

I był taki moment, kiedy zrobiłem swoje badania, że przeszedłem taki moment ekscytacji. Te wyniki były bardzo ciekawe. I stwierdziłem, że chciałbym znowu coś takiego robić, coś takiego przeżyć. [B]

Doktorat bywa postrzegany jako kontynuacja: studiów, intelektualnej aktywności, pasji, pracy w kołach lub projektach. Tym samym na podjęcie studiów doktoranckich patrzeć można nie tyle jako na jedną z dostępnych do rozważenia opcji, co na

\footnotetext{
${ }^{13}$ Badania kwestionariuszowe przeprowadzono w 2015 r. na próbie ok. 400 doktorantów pięciu uczelni warszawskich, będących ówcześnie na III roku studiów.

${ }^{14}$ Autorzy wypowiedzi oznaczeni są literami.
} 
naturalną konsekwencję wcześniejszych działań, naturalną ścieżkę kariery. Jest to szczególnie widoczne w poniższej wypowiedzi:

Jakoś to naturalnie wyszło. Moja promotor, z którą w kole naukowym ściśle współpracowałyśmy, powiedziała - no, to składaj papiery, już temat mamy. Tak się złożyło, jakoś tak wyszło. To było takie - po prostu trzeba to zrobić. To jest kolejny krok, tak jak, nie wiem - jak ślub po narzeczeństwie. To koło naukowe tak mnie w tę naukę wbiło, że już na studiach ze wszystkimi w zakładzie znaliśmy się jak łyse konie. Więc po prostu na takiej stopie były te relacje, że nie wyobrażałam sobie [odmówić]. [C]

Traktowanie studiów doktoranckich jako kontynuacji warto również osadzić w kontekście oceny rynku pracy przez doktorantów. Jeżeli przewidują oni, że będą musieli podjąć pracę poniżej swojej kwalifikacji i niezwiązaną z wykształceniem, to podjęcie studiów doktoranckich staje się wyrazem potrzeby używania swoich kompetencji oraz potrzeby ciągłości i nadania sensu dotychczasowej ścieżce edukacji.

Postrzeganiu doktoratu jako kontynuacji towarzyszy nieraz poczucie niedosytu, które rozmówcy wiązali z krytyczną oceną studiów magisterskich jako systemu odfajkowywania obecności i zaliczeń w celu realizacji nie najlepiej przemyślanych programów nauczania. Wyjątkowo wyraźnie wybrzmiewa to w poniższej wypowiedzi:

Kończysz studia i nagle: O Jezu, to już koniec? Miałem takie poczucie, że nie było kiedy postudiować, bo trzeba było siedzieć na zajęciach od 8 do 20 i zaliczać egzaminy. Bo to jest taki dziwny system, który oczekuje zaliczania i odfajkowywania zajęć, obecności tylko a nie takiego przechadzania się z jednym pytaniem, jak kiedyś to miało miejsce, w tej pierwszej akademii. Są jakieś zajęcia, które są poszatkowane na przedmioty, przedmioty są od siebie sztucznie oddzielone, ta wiedza jest jakoś sztucznie gromadzona, przekazywana, jakby... Jakby nasze mózgi były pendrive’ami... Dlaczego ja, młody człowiek, który chce się rozwijać, który chce wypróbowywać swoją wrażliwość, wyobraźnię, zdolności - dlaczego ma przelecieć przez te studia jak woda przez rury w klozecie i mieć z tego tylko papier. (...) Zwyczajnie czuję niedosyt. [D]

Negatywne doświadczenie studiów magisterskich jako intelektualnie niesatysfakcjonujących okazuje się więc czynnikiem zachęcającym do podjęcia studiów.

W niektórych wywiadach jako motyw pojawiła się zachęta ze strony pracowników naukowych, najczęściej promotorów. Posiadanie kogoś, kto nie tylko zachęci, ale ułatwi wejście w rzeczywistość akademicką, włączy w działania naukowo-badawcze, jak również będzie w stanie zadbać o gratyfikacje finansowe jest z pewnością okolicznością sprzyjającą karierze akademickiej, a ewentualną rezygnację czyni mniej przypadkową.

Istotne znaczenie $w$ kontekście motywów do podjęcia studiów doktoranckich mają także doświadczenia zawodowe. Wśród rozmówców znalazły się osoby, na których decyzję o doktoracie wpłynęło poczucie bycia nie na miejscu w swojej pracy, poczucie braku sensu i rozwoju. Doktorat okazał się czymś bardziej atrakcyjnym niż praca 
zawodowa dla wszystkich moich rozmówców, w tym: dla świeżo upieczonego magistra, który pracy zarobkowej nawet nie próbował podjąć, zakładając, że jest skazany na przysłowiową pracę na kasie; dla osoby, która zarobkowo wykonywała szereg rutynowych, tymczasowych i niepewnych prac; jak i dla doktorantów z bogatszym doświadczeniem zawodowym i atrakcyjnymi na rynku pracy CV. Poniższe cytaty odnoszą się do tych ostatnich:

Miałam poczucie takiego bycia nie na miejscu [w korporacji], że jestem tam tylko dlatego, że dobrze wypełniałam te zadania, że kurczę, siedzę w tym Excelu, siedzę w jakimś programie - do czego w ogóle nie trzeba mieć studiów. Więc takie to były motywacje, żeby robić coś, co jest bliższe albo studiom, albo poczuciu jakiejś przydatności... robienia czegoś wartościowego. [E]

Nienawidziłem pracy w firmie. Nienawidzę korporacji. Część mojej pracy, to było coś, czego można, myślę, nauczyć małpę. To, co oni w biznesie nazywają rozwojem - to dla mnie nie jest żaden rozwój. Mimo że nauczyłem się dobrze robić to, co robiłem, jakoś tam awansowałem, to doszedłem do punktu ogromnej frustracji. Duża część mojej pracy, robienie raportów nikomu nie potrzebnych. Bezcelowa praca. I dużo rzeczy mnie tam mierziło. A myślę sobie: jak ja mam robić to, czego nie lubię i co mnie denerwuje, a kokosów z tego tak czy siak nie będzie, to ja mam to gdzieś. No i doszedłem do wniosku, że z tego wszystkiego, co robiłem, najbardziej rozwijające i najbardziej ekscytujące dla mnie to był doktorat. [B]

Doświadczenia zawodowe moich rozmówców skłaniały ich albo do rozpoczęcia doktoratu, o którym myśleli już wcześniej, albo do powrotu do niego po przerwie. Co istotne, intelektualna atrakcyjność doktoratu jawi się jako niezależna od skali powodzenia zawodowego. Okazuje się, że nawet jeśli praca daje gratyfikację finansową i jest rozwojowa (daje możliwości nabycia wartościowych na rynku wpisów do CV lub różnych form awansu), to wciąż trudno o możliwość wykorzystania w niej umiejętności i wiedzy, które już się posiada lub też tych, które chce się rozwijać, a tym bardziej zajmowania się rzeczami ciekawymi lub mającymi w poczuciu rozmówców sens.

Wspominając motywacje do podjęcia studiów doktoranckich, rozmówcy mówili także o swoich wyobrażeniach: o możliwości poświęcenia się jakiemuś zagadnieniu; o otwarciu się możliwości instytucjonalnych; pracy w sprzyjającym, twórczym klimacie intelektualnym; o możliwości zostania nauczycielem lub badaczem. Dla większości z nich konfrontacja z rzeczywistością oznaczała negatywną weryfikację tych wyobrażeń oraz dezaktualizowała związane z nimi motywacje. Fakt ten może zwiększać znaczenie przypisywane po czasie motywacjom samorozwojowym, które mają bardziej uniwersalny charakter.

Dominującą motywacją do podjęcia studiów doktoranckich pozostaje rozwój i doskonalenie, które należy osadzić w kontekście niedosytu dwojakiego rodzaju. Po pierwsze, niedosytu rozwoju na studiach magisterskich, co warto odnieść do problematyki umasowienia studiów magisterskich, obniżenia ich poziomu oraz inflacji dyplomu. Po drugie, niedosytu rozwoju w pracy poza uczelnią, co z kolei wiąże się z charakterystyką 
polskiego rynku pracy, a także być może lokalną kulturą organizacyjną. W tym kontekście studia doktoranckie stają się wyborem naturalnym, a wręcz mentalną koniecznością. Korzyści z uzyskanego tytułu i plany na dalszą przyszłość wydają się w tym kontekście drugorzędne. Na doktorat należy zaś spojrzeć szerzej niż się przyjęło w alternatywie: przygotowanie do pracy naukowej lub zawodowej albo przez przeciwstawienie sobie wartości instrumentalnych i autotelicznych (Domaradzka, Walczak 2013). Staje się on formą realizacji takich potrzeb, jak: bycie człowiekiem wykształconym, doskonalenie się, zajmowanie się czymś ciekawym, wartościowym, realizowanie się w dziedzinie swoich kompetencji - które to potrzeby należy przypisać porządkom tożsamości, samorealizacji czy wartości.

\section{Doświadczenia pracy na uczelni i poza nią: wyzwania i sposoby radzenia sobie}

Doktoranci stoją przed trzema zasadniczymi wyzwaniami: jak zrobić doktorat, jak się w tym czasie utrzymać i jak pogodzić jedno z drugim. Badanie odsłoniło szereg wariantów radzenia sobie z tymi wyzwaniami. Trudno o typologię, która nie przysłoniłaby istotnych różnic między nimi. Możliwe jest za to wyróżnienie kluczowych dla tychże wariantów czynników:

1. Sytuacja na uczelni, w szczególności: regulacje dotyczące stypendiów; praktyki zatrudniania doktorantów w projektach lub na stanowiskach asystenckich; wsparcie w zdobywaniu grantów; wsparcie merytoryczne i organizacyjne; nieformalne obowiązki.

2. Sytuacja zawodowa: posiadanie pracy; bezpieczeństwo pracy, w szczególności zatrudnienia, dochodu i reprodukcji umiejętności ${ }^{15}$; atrakcyjność dla rynku pracy; warunki dot. czasu i miejsca pracy.

3. Sytuacja osobista, w szczególności: zasoby materialne (mieszkanie, samochód, ubezpieczenie zdrowotne) i finansowe ze źródeł innych niż uczelnia i praca; wsparcie bliskich; sytuacja rodzinna.

Stanowią one kontekst niezbędny dla zrozumienia problemów, z jakimi mierzą się doktoranci, oraz ich sposobów działania. W poniższym artykule nie jest jednak możliwe omówienie ich wszystkich. W dalszej części koncentruję się na głównych wyzwaniach, trudnościach i strategiach, jakie wyłaniają się z wywiadów, i w ten sposób odnoszę się do niektórych z przedstawionych wyżej czynników.

We wstępie artykułu przedstawiono kwestie związane $z$ finansowaniem doktorantów przez uczelnie. Wynika z nich, że dla większości rozpoczęcie studiów jest decyzją z perspektywy finansowej nieracjonalną, jeśli nie posiadają innych źródeł utrzymania - bliskich, pracy, oszczędności. W wywiadach potwierdził się krytyczny stosunek doktorantów do systemu stypendialnego i grantowego jako trudno dostępnego

15 Są to niektóre z rodzajów bezpieczeństwa związanego z pracą wyróżnionych przez Guya Standinga na potrzeby wyjaśnienia zjawiska prekaryzacji pracy (Standing 2012: 49). 
oraz niewystarczającego dla utrzymania się. Przedmiotem krytyki były także zasady finansowania, które promują ilość ponad jakość. W odpowiedzi na ten problem jedni decydują się zacisnąć zęby, licząc, że kiedyś uda im się wyrwać z pułapki produkcji naukowej niskiej jakości. Drudzy odrzucają walkę o punkty, stawiając na inne źródła utrzymania. Oznacza to, iż na decyzję o strategii studiowania ma wpływ nie tylko dostępność stypendiów i ich poziom, ale także zasady ich przyznawania i rodzaj pracy, której wymagają. Możliwy jest na przykład scenariusz, w którym doktorant ogranicza swoje zaangażowanie w zdobywanie punktów po to, by uprawiać naukę wysokiej jakości i decyduje się na pozyskiwanie środków do życia na zewnątrz. Mimo instrumentalnego podejścia do pracy pozaakademickiej może ona go zaangażować i znacznie utrudnić pracę naukową, a nawet odsunąć rozpoczynającego naukowca od jego pierwotnego celu.

Na stosunek wobec doktoratu rzutują także obowiązki doktorantów. Doktoranci nie odrzucają zasadności swoich obowiązków formalnych i biurokratycznych per se, ale krytykują na przykład obowiązek prowadzenia zajęć z tematów, na których się nie znają, czy niedostosowaną do ich potrzeb ofertę kształcenia, a więc to, co pochłania ich czas, a nie jest ich zdaniem przydatne. Za najpoważniejszy problem uważają natomiast takie obowiązki, jak pilnowanie studentów na egzaminach, prowadzenie recepcji podczas konferencji czy inne prace sekretarskie, oraz prowadzenie dydaktyki bez wynagrodzenia, pisanie recenzji „na zamówienie” czy wykonanie indeksu do wielotomowego dzieła. Są to zadania narzucane i egzekwowane zazwyczaj w sposób nieformalny oraz niepowiązane $z$ finansową gratyfikacją. Nie tylko zabierają one czas, ale także, ze względu na swoją nieprzewidywalność, utrudniają jego organizację i planowanie. Rzutuje to negatywnie nie tylko na pracę naukową, ale także na możliwości zarobkowania.

Należy więc odróżnić obowiązki regulaminowe (uciążliwe, ale relatywnie przewidywalne i akceptowane) i pozaregulaminowe (mniej przewidywalne i wywołujące napięcia). W literaturze nt. studiów doktoranckich określa się je zazwyczaj mianem pracy nieformalnej. Wzbogacające może być spojrzenie na to zjawisko przez pryzmat pojęcia pracy na rzecz pracy (work for labour), stosowanego m.in. przez Standinga (2014). Są to wszelkiego rodzaju wysiłki nakierowane na zdobycie lub utrzymanie pracy, które wykonywane są poza jej czasem i nie wiążą się z bezpośrednią gratyfikacją finansową. Jest to zarówno wysyłanie CV i chodzenie na rozmowy kwalifikacyjne, podnoszenie swoich kwalifikacji (finansowane z własnych środków), jak i praca nad zdobywaniem kolejnych (niepewnych) projektów i środków. Zjawisko to jest oczywiście wpisane w każdą karierę zawodową, niemniej jednak Standing zwraca uwagę na jego natężenie i kolonizowanie czasu przez tego rodzaju aktywności. W obliczu wysokiej konkurencji i niepewności pracy trzeba nieustająco podnosić swoją zatrudnialność (employability), a pracy na rzecz pracy trudno postawić granicę. Pozycja doktorantów na akademickim rynku pracy jest właśnie taka: niepewna i poddana silnej konkurencji. Im jest to silniejsze, tym silniejsza jest presja na rzecz pracy i podnoszenia swojej 
zatrudnialności (np. przez akceptowanie kolejnych obowiązków czy nawet dobrowolne zgłaszanie się do nich). Zjawisko to jednoznacznie uprzywilejowuje osoby, które mogą sobie na to pozwolić, czyniąc zasoby finansowe istotnym warunkiem zatrudnialności na uczelni ${ }^{16}$.

Jeśli nie posiadają środków do życia pozwalających na brak dochodu lub niski dochód, z jakim wiąże się rozpoczęcie studiów doktoranckich, zmuszeni są podjąć się pracy zarobkowej poza nią.

\section{Godzenie doktoratu i pracy: brak czasu}

Pracujący doktoranci, z którymi rozmawiałam, minimalizują swoje zaangażowanie w życie uczelni, unikają darmowej pracy i nie tracą czasu na "stukanie punktów". Można by więc sądzić, że mogą się w wolnym czasie poświęcić pracy naukowej. Niestety, krytycznie oceniają swoje zaangażowanie na tym polu. Czas na doktorat zjadany jest przez zajęcia, zaliczenia, czasem prowadzenie dydaktyki, realizację wymagań do otwarcia przewodu i inne obowiązki okołodoktoratowe. Praca zawodowa, ze względu na obowiązki wynikające ze stosunku pracy oraz zależność ekonomiczną, w sytuacjach konfliktu staje na pierwszym miejscu. Poza tym wiąże się nieraz z nadgodzinami, pracą w weekendy, wymogiem dyspozycyjności. Czasu na pracę naukową nie zostaje wiele:

Życie naukowe zaniedbałam całkowicie. Ale to przez nadmiar wyjazdów, na które się świadomie zdecydowałam, bo taka okazja się prędko nie powtórzy. Dużo się tam uczę. Poza tym to się wiąże z zarobkami. [F]

To znaczy pogodzenie tego wszystkiego jest dla mnie bardzo trudne. (...) robiłem tyle rzeczy okołodoktoratowych, jak ja to nazywam, które były moim zdaniem zbędne, plus do tego jeszcze praca, że fizycznie - miałem też kłopoty ze zdrowiem - fizycznie nie dałem rady pracować stricte nad samym doktoratem. [B]

Mam poczucie, że praca zabiera mi lwią część mojego dnia. Ze względu nawet na to, że gdy nie jestem w pracy, a jest jakaś sytuacja kryzysowa, to ja muszę być pod Internetem. Więc to mi troszeczkę nachodzi na inne obowiązki. [A]

Autorzy powyższych wypowiedzi mieli przywilej posiadania prac w pewnych aspektach atrakcyjnych: rozwojowych albo dobrze płatnych. Można by więc powiedzieć, że powinni zmniejszyć swoje zaangażowanie w pracę lub wręcz dokonać wyboru: praca albo doktorat, nie zaś próbować chwytać dwie sroki za ogon. Jednak osobom młodym, dopiero budującym swoją pozycję zawodową, trudno wynegocjować z pracodawcą mniejszy zakres godzin czy obowiązków, nie mówiąc o ryzyku finansowym, jakie

${ }^{16}$ Oczywiście nie można twierdzić, iż poziom zaangażowania w działania na uczelni przekłada się bezpośrednio na szanse zatrudnienia i wypiera całkowicie kwestie merytoryczne. Niemniej jednak osoby pozostające na co dzień poza uczelnią z pewnością zmniejszają swoje szanse wobec tych, które wykonują szereg zadań, licząc na formalizację tego stanu rzeczy w postaci zatrudnienia. 
by się z tym wiązało. A rezygnacja z dobrej pracy na rzecz niepewnej kariery w nauce wydaje się posunięciem skrajnie nieracjonalnym. Dlatego też mimo poczucia konfliktu doktoranci trwają w tej sytuacji, zdając sobie często sprawę, iż jest ona na dłuższą metę trudna do utrzymania. Za przykład tej konfliktowej sytuacji niech posłuży historia osoby, która próbowała łączyć pracę zawodową i doktorat, dwukrotnie zmieniając relacje ich wzajemnego podporządkowania, i dwukrotnie ponosząc porażkę:

Pierwszy semestr [w nowej pracy] minął tak jakoś dosyć lekko, dałem radę zaliczyć wszystko w zasadzie zdalnie. Drugi semestr już był problematyczny, bo miałem taki nawał pracy w związku z coraz większą liczbą obowiązków, że już nie dałem rady tego zaliczyć, połączyć pracy ze studiami. I w zasadzie to się tak samoistnie rozeszło, ja nie powiedziałem, że rezygnuję, ale też nie mogłem przyjeżdżać, nie mogłem zaliczać, więc de facto zrezygnowałem. (...) [Po powrocie na studia doktoranckie:] I na początku oszukiwaliśmy się wszyscy z moją szefową, że będę normalnie pracował, tylko zdalnie - ale to się oszukiwaliśmy. Dosyć krótko to trwało [śmiech]. [G]

Mój rozmówca mógł ostatecznie zrezygnować z pracy i zaangażować się w naukę m.in. dzięki zgromadzonym oszczędnościom. Ma jednak świadomość, że za jakiś czas znów będzie musiał szukać pracy i sprostać wyzwaniu godzenia jej z nauką.

W uprzywilejowanej pozycji znalazł się doktorant, któremu udało się wypracować układ, będący dla wielu z moich rozmówców wyobrażonym rozwiązaniem ich kłopotów. Posiadając ugruntowaną pozycję zawodową oraz zawód pozwalający na elastyczne godziny pracy, zdecydował się kontynuować wcześniej zarzucony doktorat, godząc się na większą niestabilność wynagrodzenia i czasu pracy. Choć twierdzi, iż znajduje się w wyjątkowo komfortowej sytuacji w porównaniu do innych doktorantów, to i tak mierzy się z trudnościami związanymi z czasem i finansami:

Ja jestem głęboko przekonany, że wielu doktorantów ma dużo większe problemy finansowe czy z pogodzeniem tego wszystkiego. Ale nawet jeżeli ja nie mam takich problemów, to mam problemy z tym, żeby czasowo i fizycznie się wyrobić. Dlatego mój doktorat się ciągnie jak papier toaletowy. Co też nie jest fajne, no sorry. Ja bym chciał sobie trochę obciąć tych zajęć [zawodowych] i zająć się tym doktoratem, tak? Ale po prostu zawsze kończy się tym, że się rozjeżdżam finansowo. [B]

Konflikt między pracą zawodową i naukową przybiera inny charakter w przypadku osoby, której w ciągu roku od utraty pracy udawało się znajdować zajęcia trwające nie dłużej niż 3 miesiące. Sygnalizowane przez nią problemy wydawać się mogą charakterystyczne dla osób polegających na pracach krótkoterminowych:

W zeszłym roku powiedziałabym, że tak [udawało się nie zaniedbywać doktoratu]. A teraz bardzo przytłaczająca jest ta perspektywa poszukiwania pracy. Nieustannego poszukiwania pracy. Choć teraz pracuję, to to jest tymczasowe, i to się niedługo skończy. I trzeba będzie znowu szukać. Najlepiej już teraz zacząć, bo już potem się nie znajdzie. (...) Samo poszukiwanie kolejnych ofert pracy zajmuje bardzo dużo czasu. Zawsze w takich okresach, kiedy intensywnie szukam pracy, ten doktorat odchodzi na dalszy plan. [H] 
W sytuacjach niestałości/braku pracy i dochodu ich poszukiwania mogą stać się pracą samą w sobie i być równie obciążające jak „normalna” praca, tym bardziej ze względu na presję psychiczną, z jaką wiąże się brak dochodów.

Złudnym byłoby jednak myśleć, iż brak czasu jest problemem jedynie osób szukających środków utrzymania poza uczelnią. Problem akademickiej pracy na rzeczy pracy i presji na zatrudnialność przedstawił doktorant, który właśnie ukończył pierwszy rok studiów:

Siedzę i piszę. Bo chcę mieć pewne stypendium. Ale czuję, że to jest za mało. Pracuję od poniedziałku do niedzieli, tak naprawdę cały czas, a to i tak jest za mało. Jedno to jest pasja i chęci i motywacja. I że jest się zwyczajnie zaabsorbowanym jakimś problemem. Ale jeżeli jeszcze dochodzi do tego presja, że - jeżeli nie wyrobię pewnej normy - to zwyczajnie nie będę miał zapewnionego bytu (...). No więc muszę siedzieć od poniedziałku do niedzieli i robić. Bo mam poczucie, że znowu może mi pięć setnych zabraknąć [do stypendium]. I nie wiem, jeśli nie dostanę tego stypendium, to nie wiem czy nadal będę widział w tym sens. Nie robię tego dla pieniędzy. Ale nie da się żyć powietrzem. [D]

Dwie powyżej zacytowane wypowiedzi dobrze oddają praktyczny i psychologiczny wymiar zjawiska wykonywania pracy na rzeczy pracy (w pierwszym przypadku, by zdobyć pracę, w drugim, by zdobyć stypendium). Jest ona czasochłonna, a czas ten nie jest wynagradzany, jest bowiem inwestycją w przyszłość. Jest to jednak inwestycja niepewna, a tymczasem od jej rezultatów zależy przyszłość, co wywołuje uczucie presji i psychicznego obciążenia.

Brak czasu na pracę naukową jest zapewne problemem wspólnym dla wielu akademików, niezależnie od wieku i stanowiska. Niemniej sytuacja doktorantów jest o tyle odmienna, że dla większości z nich uczelnia nie jest żadną przystanią, w której mogliby się cieszyć elementarną stabilności finansową i z której mogliby planować dalszą karierę czy podejmować się dodatkowych aktywności. Inwestowanie w pracę na rzecz pracy na uczelni w obliczu dużej konkurencji wydaje się ryzykownym posunięciem, a walka o finansowanie $z$ nauki wiąże się z wejściem w system, który wielu doktorantów zniechęca. Zarobkowanie poza uczelnią wydaje się rozsądne, ale wobec realiów rynku pracy młodych spycha ono pracę naukową na margines, niezależnie, jaką pracę posiadają (satysfakcjonującą i dobrze płatną czy też nie, w pełnym lub niepełnym wymiarze, krócej lub dłużej terminową).

Doktoranci nie żyją jednak samym zarabianiem pieniędzy i nauką. Przyjrzyjmy się teraz problemom związanym z czasem w całożyciowym kontekście życia doktorantów. 


\section{Godzenie pracy, doktoratu i innych aktywności:}

\section{hiperaktywność i jej granice}

Większość rozmówców łączyła pracę zarobkową i doktorat z dodatkowymi aktywnościami: innymi studiami/kursami, zaangażowaniem w samorząd, hobby czy byciem rodzicem. Według francuskich socjologów Luca Boltańskiego i Eve Chiapello (Boltanski, Chiapello 2005) aktywność jest podstawową cechą wzorcowego człowieka nowego kapitalizmu" ${ }^{17}$. Cechuje go także adaptacyjność, mobilność, szerokie sieci znajomości, wszechstronność, ale to nieustająca aktywność jest jego najważniejszą właściwością. Jest to nie tyle opis rzeczywistych ludzi, co ideał zawarty w przekazie kulturowym, w weberowsko rozumianym nowym "duchu kapitalizmu". Analizę aktywności doktorantów warto wpisać $w$ refleksję nad oczekiwaniami wobec człowieka i pracownika, stawianymi przez nowy kapitalizm, m.in. by zaobserwować ich możliwe konsekwencje. W dalszej części tekstu będę się posługiwać terminem hiperaktywności, jako że aktywność cechuje, jak sądzę, większość ludzi, a jak stanie się jasne w dalszej części wywodu, poruszam tu problem aktywności zmierzającej ku swoim granicom.

Analizę rozpocznę od przypadku osoby, której udawało się do tej pory efektywnie, w swojej ocenie, łączyć wiele różnych działań. Poza wspomnianymi niżej pracą, doktoratem i blogiem, od czasu do czasu bierze ona dodatkowe zlecenia, pozostaje w związku, a w weekendy odwiedza rodzinę:

Mam pracę na cały etat, ale jestem elastyczna w tym, kiedy mogę sobie usiąść do pracy. Teraz, kiedy są wakacje, mogę to sobie robić w normalnym schemacie - w sumie już jestem o szóstej na nogach, do czternastej zawsze ten czas się staram przeznaczyć na pracę, żeby później mieć chwilę wolnego dla siebie i czas na inne obowiązki. Ale na przykład jeżeli jest rok akademicki i wiem, że będę miała od tej do tej zajęcia, to staram się przeznaczyć tylko na nie czas. (...) Moja praca jest moim hobby, ale też mam inne hobby, które nie jest związane z pracą ani z działalnością naukową. Prowadzę swojego bloga (...) Na więcej nie starcza mi czasu niestety. No i seriale, dużo seriali oglądam. (...) Przy jakimś tam usprawnieniu tego swojego zarządzania czasem to nie jest niemożliwe. Jest trudne, ale nie niemożliwe. [A]

Rozmówczyni jest osobą pełną energii i pasji, starającą się zawsze łączyć przyjemne z pożytecznym, a tym samym zmotywowaną, a także dobrze zorganizowaną i zdyscyplinowaną. Są to bez wątpienia cechy sprzyjające efektywnej hiperaktywności. Niemniej jednak przypadek ten unaocznia również wagę sprzyjających okoliczności zewnętrznych. Rozmówczyni ukończyła dopiero pierwszy rok doktoratu, w trakcie którego miała stabilną pracę i dochód, a jednocześnie elastyczne godziny, co wydaje się istotnym kontekstem jej aktywności. Jednocześnie jej praca jest dla niej interesująca i rozwijająca. W perspektywie ogólnej refleksji nad życiem doktorantów warto się zastanowić nad możliwością trwania takich warunków zewnętrznych oraz zasobów energetycznych w dłuższej perspektywie czasowej.

17 Precyzyjnie mówiąc, chodzi o warunki bycia Wspaniałym Człowiekiem (the condition of a Great Man) w porządku projektowym (projective city), który staje się dominujący m.in. w sferze pracy. 
Przywoływana rozmówczyni, a także inni badani, mówili o konieczności dobrego zarządzania swoim czasem i stosowaniu aplikacji do planowania zadań, czy opisywania zajęć w kalendarzu co do godziny. Być może młodzi, ambitni ludzie nie planują $w$ dalekiej perspektywie, co $w$ dyskursie publicznym jest częstym wobec nich zarzutem, za to specjalizują się w precyzyjnym planowaniu w krótkiej. Staje się to wymogiem realizacji hiperaktywności.

Elementem zarządzania czasem staje się także jego rozgraniczanie na poszczególne sfery życia. Poniższe cytaty ilustrują problem rozmywania się granic między czasem prywatnym i publicznym, czasem pracy i niepracy oraz wysiłek podejmowany na rzecz uporządkowania swojej codzienności:

Weekendy to taka świętość. Staram się nie [nie poświęcać czasu na pracę], nawet maila nie odbieram. Od niedawna, bo kiedyś w weekend potrafiłam przyjechać [do pracy na uczelni], ale teraz staram się nie. [C]

Staram się brać ze sobą komputer, ze względu na to, że muszę być cały czas online, ale staram się to bardzo rozgraniczyć. Żeby naprawdę nie robić dwóch rzeczy po łebkach, bo się później nie odnajdę w tym, co robię. I staram się przeznaczyć weekend tylko i wyłącznie dla moich spraw domowych, moich spraw związanych z rodziną, przyjaciółmi. Bo tego mi brakuje w takim normalnym tygodniu pracy. W niedziele zdarza mi się pracować, ale tego wymaga ode mnie specyfika mojej pracy, ale to już jest zazwyczaj wieczorem. [A]

Więc strategią moją był rzeczywiście taki twardy podział. Że wracam do domu i się zajmuję tylko sprawami uniwersyteckimi. No i weekendy, weekendy też. Ale też w weekendy kursy miałem, swoje takie ogólnorozwojowe, więc to też czasami na doktorat nie miałem czasu. [G]

Jak widać, nie zawsze udaje się stosować do własnych zasad i są one przedmiotem nieustających negocjacji. Nie sposób jednak funkcjonować bez prób ich ciągłego ustalania i egzekwowania.

Istotną kompetencją w kontekście godzenia różnych pól aktywności okazuje się również asertywność. Przydatna zarówno na uczelni, kiedy zdarzają się propozycje bezpłatnych lub niskopłatnych, albo po prostu czasochłonnych i nieprzydatnych prac. Jak również przydatna w pracy, w której normą stają się nadgodziny, praca w weekendy, a nowe obowiązki zwykło się cedować na młodych pracowników:

Momentami nie miałem opcji, żeby odmówić. No bo ktoś wpływowy, a nie wiem, w jakiej jeszcze sytuacji się znajdę. Zastanawiałem się, czy mieć skrupuły, czy nie mieć. Tak naprawdę uchodzę za niepokornego doktoranta, co ma tupet. Ale, szczerze powiedziawszy, nie mam teraz takiego problemu, jak niektóre moje znajome, że przychodzi do nich promotor i mówi, żeby mu zrobiły indeks do kilkutomowej książki. [D]

Teraz kiedy sama sobie organizuję pracę, to może tak nie przesadzam z nadgodzinami. Ale kiedy to nie zależało ode mnie, to potrafiłam przesiedzieć pół nocy. (...) I też to, że w międzyczasie nauczyłam się asertywności i umiem ocenić, na co starczy mi czasu, a co wejdzie na mój czas spania. I wtedy potrafię odmawiać. [F] 
No i problemem było to, że poszedłem do korpo z myślą, że będę dalej się rozwijał na doktoracie, a miałem zderzenie, że jednak to było za dużo. Ale to mogła być też moja wina, bo ja czując, że dostaję coraz więcej obowiązków, nie mówiłem dość. [G]

Doktoranci muszą nieustannie ważyć możliwe korzyści i straty związane z decyzją o przyjmowaniu/odmawianiu zadań, co jest szczególnie trudne w obliczu niepewności kariery i na uczelni i poza nią. Radzenie sobie (techniczne, ale też psychiczne) z koniecznością stawiania granic staje się kolejną istotną kompetencją doktoranta.

Starając się pogodzić wiele różnych aktywności, doktoranci ćwiczą się w zarządzaniu czasem, stawianiu granic między różnymi sferami życia oraz wobec stawianych im oczekiwań. Z przytoczonych wypowiedzi wynika jednak, że jest to nie tyle nauka, co nieustająca walka, a stosowane metody nie zawsze są wystarczające.

Granicę hiperaktywności wyznaczają również jej negatywne konsekwencje. W tym kontekście doktoranci mówili najczęściej o doświadczeniu nigdy niekończącej się pracy. Jedna z rozmówczyń używała dla opisu tego odczucia określenia „syndrom wiecznie nieodrobionej pracy domowej":

Niefajny jest syndrom wiecznie nieodrobionej pracy domowej. To jest taki smrodek, który po prostu się ciągnie od pierwszego roku studiów, od pierwszego dnia. To jest coś, co nas męczy, i to jest naprawdę - czuje się ten permanentny stres. (...) zawsze się coś ciągnie, zawsze. [C]

Inny rozmówca zwrócił uwagę na fakt, iż presja na pracę wypiera inne sfery życia:

W pewnym momencie złapałem się na tym, że mama czy tata zadzwonili, pół godziny rozmawialiśmy. I ja po odłożeniu telefonu złapałem się, że kurczę, ja przez te pół godziny mogłem coś przeczytać. Do takich momentów dochodzę, że, żałuję, że odebrałem, żałuję, że poświęciłem na to czas, że czuję, że życie prywatne mi przeszkadza. [D]

O ile pewien stopień stabilizacji, jaki z czasem osiągają doktoranci, ułatwia radzenie sobie z presją napędzaną poczuciem, że skoro można jeszcze coś zrobić, to znaczy, że trzeba (bo inaczej nie dostanę stypendium, nie zostanę zatrudniony na stałe), to pozostaje nigdy niekończąca się lista zadań. Może to wynikać z realnego nadmiaru obowiązków w stosunku do czasu przewidzianego na ich realizację (częste w pracy zawodowej) albo też z rozbijania rytmu pracy przez nagłe zadania albo natłok obowiązków biurokratycznych (problem poruszany w szczególności w kontekście uczelni).

Moi rozmówcy bardzo różnie radzą sobie z nadmiarem obowiązków. Przede wszystkim realizują je kosztem życia prywatnego: rodzinnego, towarzyskiego, aktywności o charakterze relaksacyjnym i regenerującym. Niepokojąca wydaje się w szczególności reakcja w postaci psychicznego wycieńczenia, która objawia się spadkiem energii czy oddawaniu się rozrywkom nie tyle regenerującym, co wyłączającym, "odmóżdżającym": 
Miałem na przykład takie sytuacje, że umówiliśmy się z przyjaciółmi, i nagle - jestem taki wyautowany, zero energii. I nic się nie stało dramatycznego - tylko taki spadek energii psychicznej, że jedziesz na zatartym silniku. Ale trochę mnie to przeraża, że nie będę miał siły psychicznej czerpać radości z czegokolwiek. [D]

Włączam sobie takie odmóżdżenie jak wracam. Nic mi się nie chce, naprawdę. [C]

Inną konsekwencją trudności w godzeniu różnych sfer aktywności obecną w prowadzonych wywiadach były wielorakie frustracje: wynikająca z porażek w godzeniu różnych potrzeb, celów i wartości; wynikająca z trudności w planowaniu, z liczby niekontrolowanych czynników, które rozbijają rytm pracy; frustracja poczuciem niemocy zamknięcia jednego etapu i rozpoczęcia nowego. Efektem omówionych problemów była także zmiana priorytetów, w tym motywacja, żeby coś zmienić, aby móc doktorat naprawdę szybko zakończyć. Nasuwa się jednak pytanie, czy zmiana ta jest możliwa oraz czy "na zatartym silniku" uda się moim rozmówcom dotrzeć do celu.

Konkludując, model finansowania doktorantów sprawia, iż wszyscy ci, którzy nie studiują w jednostkach, które opracowały systemy sprzyjające poświęceniu się pracy naukowej, zmuszeni są zabezpieczyć sobie zewnętrzne źródła utrzymania - innych członków rodziny, oszczędności czy pracę zarobkową (albo też chwiejne konfiguracje tych elementów $)^{18}$. Niezależnie jednak od wariantu finansowania się doktoranci mówią o braku czasu na pracę naukową, albo ze względu na obowiązki okołodoktoratowe i uganianie się za punktami w systemie stypendialno-grantowym, albo ze względu na angażującą pracę zawodową czy jej poszukiwania. Wszyscy oni konfrontują się także z oczekiwaniami systemowymi wykonywania pracy na rzecz pracy. Godzenie różnych pół aktywności doktorantów wymaga sprzyjających okoliczności zewnętrznych, a także ćwiczenia się w umiejętności zarządzania czasem i asertywności. Hiperaktywność ma jednak swoje granice i oznacza w praktyce nieustającą walkę z czasem, której pierwszą ofiarą jest życie prywatne.

Skoro doktorat oznacza nieustającą niepewność finansową, niepewność przyszłej kariery, chwiejność bilansu zysków i strat, psychiczny dyskomfort związany z koniecznością materialnego i finansowego polegania na innych w dorosłym życiu, oszczędzanie na swoich fizycznych i psychicznych potrzebach, to narzuca się pytanie, czemu doktoranci nie porzucają go natychmiast, gdy zorientują się jak wyglądają realia?

\section{Czemu doktoranci nie rezygnują ze studiów?}

Na podstawie wypowiedzi rozmówców wyróżnić można trzy logiki myślenia, które decydują o kontynuowaniu doktoratu. Pierwszym z nich jest logika konsekwencji, która każe myśleć: skoro tyle czasu, energii, pieniędzy w to zainwestowałem, to nie

${ }_{18}$ Pozostaje jeszcze możliwość wyjazdu na studia za granicą, co jest strategią wymagającą zupełnie odrębnego omówienia. Warto jednak odnotować, że jest to strategia rzadka, często związana z koniecznością zainwestowania sporych środków oraz przysparzająca wielu trudności życiu osobistemu. 
mogę przecież tego porzucić: „byłoby szkoda”, ,byłoby to marnotrawstwo", „byłoby to nieodpowiedzialne". Potrzeba kończenia rzeczy czy trudność z zaakceptowaniem utraty dokonanych inwestycji mogą przysłaniać inne racjonalne argumenty, takie jak brak perspektyw kariery akademickiej, niewielkie/niepewne korzyści w życiu zawodowym, już poniesione koszty finansowe czy osobiste oraz koszty, które jeszcze trzeba będzie ponieść.

Kolejną logiką jest logika trwania. Jeśli doktorat organizuje istotną część życiowych aktywności: czas pracy, jej miejsce, relacje społeczno-zawodowe, a jednocześnie sytuacja życiowa pozwala na niski dochód, to jego porzucenie, mimo wszelkich trudności i wątpliwości, nie jest nawet przedmiotem refleksji. Stan ten właściwie oddaje strategia jednej z rozmówczyń:„Na razie żyję tym, co jest”.

Sposobem uzasadniania kontynuacji studiów staje się z czasem także przekonanie, że choć może doktorat nie jest szczególnie cennym zasobem na rynku pracy, to jednak „raczej otwiera furtki, niż zamyka”, czy innymi słowy:„, na pewno mi nie zaszkodzi”.

Powyższe sposoby myślenia stanowią istotną motywację do trwania na studiach doktoranckich. Z przeprowadzonych rozmów wyłania się jednak jeszcze jedna, być może najważniejsza motywacja. Dla wielu moich rozmówców, wobec szeregu trudności i rozczarowań, dezaktualizacji wielu z motywacji, doktorat staje się sposobem na realizację swoich potrzeb intelektualnych, robienia czegoś w ich mniemaniu sensownego, wartościowego, lub po prostu interesującego:

Praca związana z doktoratem była przynajmniej jakaś intelektualna, wymagająca myślenia wiedzy, łączenia pewnych wątków. Dająca możliwość jakiejkolwiek dyskusji. A ta praca zawodowa tak naprawdę była taka... głupiego robota. $[\mathrm{H}]$

Może mi to dawać tylko satysfakcję prywatnie, rozwój zainteresowań, kontakt z super specjalistami, kontakt ze świetnymi osobami, które naprawdę robią ciekawe doktoraty. [F]

Należałoby zatem stwierdzić, że doktoranci kontynuują studia mimo swych doświadczeń akademickich oraz ze względu na doświadczenia zawodowe. Jednocześnie doświadczenia zawodowe mogą stać się główną przyczyną nieuzyskania przez nich stopnia doktora.

\section{Zakończenie}

Zbadani doktoranci odnajdują w studiach możliwość rozwoju i samorealizacji, której nie dały im ani umasowione studia drugiego stopnia, ani niepewny i mało atrakcyjny rynek pracy. W tym świetle rozważanie orientacji doktorantów wg alternatywy kariera akademicka albo zawodowa wydaje się nieadekwatne. Stąd zapewne pochodzi częste przekonanie, iż studia doktoranckie to hobby. Wydaje się to jednak zbyt dalece idącym wnioskiem, zważywszy na poziom zaangażowania intelektualnego i czasowego, jakiego wymagają. Bardziej zasadnym wydaje się sądzić, iż w obliczu niepewności 
zarówno kariery akademickiej, jak i pozaakademickiej podejmowanie prób na obydwu tych polach równocześnie staje się sposobem na dywersyfikację możliwości zawodowych (w tym dywersyfikację kompetencji, doświadczeń zawodowych czy sieci kontaktów). $Z$ tej perspektywy doktorat nie jest więc jedynie źródłem niepewności, jest także strategią jej niwelowania.

Strategia ta wiąże się jednak z wieloma problemami, które czynią doktorantów ciekawym przykładem pracowników nowego kapitalizmu. Można ich opisać jako bliskich wzorcowi idealnego pracownika tych czasów: aktywni, mobilni, wszechstronni, zdobywający nowe doświadczenia, kompetencje i kontakty. Jednocześnie ich doświadczenia rzucają światło na możliwe praktyczne oblicza tego wzorca, które odzwierciedlają problemy opisywane w kontekście współczesnych przemian pracy - ich sytuacja życiowa i zawodowa jest niestabilna, a ich przyszłość dalece niepewna. Ich praca jest w przeważającej mierze niewynagradzana, a traktowana jako inwestycja w przyszłość (praca na rzecz pracy). Doświadczają oni presji na podnoszenie swojej zatrudnialności w warunkach wysokiej konkurencji, co prowadzi ich do poczucia, że praca nie ma końca. Hiperaktywność jako sposób radzenia sobie z zastaną sytuacją napotyka swoje granice w postaci psychicznego i fizycznego przemęczenia.

Ich czas jest skolonizowany przez pracę, choć jednocześnie jest to praca, która nie daje poczucia zakorzenienia, nie gwarantuje przynależności do wspólnoty i tożsamości. Bycie doktorantem jest co prawda rodzajem tożsamości, zwłaszcza wobec braku takowej zakotwiczonej na rynku pracy, ale jest to tożsamość tymczasowa i zastępcza.

Doświadczenia doktorantów mają także niebagatelne znaczenie z perspektywy przyszłości akademii, bowiem to spośród nich wyłonią się jej przyszłe kadry. Skłaniają do refleksji nad rzeczywistymi procesami selekcji do nauki, jakie dokonują się w warunkach współczesnego akademickiego i pozaakademickiego rynku pracy. Determinacja i predyspozycje do kariery naukowej pozostają z pewnością ważne, czy jednak waga zasobów ekonomicznych, sytuacji rodzinnej oraz adaptacyjności do systemu punktowego jest wystarczająco rozpoznana i, co najważniejsze, pożądana?

\section{Bibliografia}

Bień D., 2016, Studia trzeciego stopnia w polskich uczelniach - funkcjonowanie, diagnoza, Rekomendacje "Nauka i Szkolnictwo Wyższe”, nr 1(47).

Bień D., Czy doktoranci są prekariuszami, artykuł udostępniony autorce przed publikacją.

Boltanski L., Chiapello E., 2005, The New Spirit of Capitalism, London:Verso.

Dąbrowa-Szefler M., Sztabiński P.B., 2008. Model kształcenia doktorantów. Wnioski z badań, Warszawa: Centrum Badań Polityki Naukowej i Szkolnictwa Wyższego UW.

Dokowicz M. i in., 2014, Diagnoza stanu studiów doktoranckich 1.0. Najważniejsze Problemy, Warszawa: Krajowa Reprezentacja Doktorantów.

Domaradzka A., Walczak D., 2013. Wartość autotelicza czy instrumentalna? Rola studiów doktoranckich w opinii kierowników studiów i doktorantów, "Nauka i Szkolnictwo Wyższe”, nr 2(42). 
GUS, 2007, 2011, 2015, Szkoły wyższe i ich finanse, Warszawa: GUS.

GUS, 2017, Rocznik Statystyczny RP, Warszawa: GUS.

Eurostat, http://ec.europa.eu/eurostat/web/lfs/data/database.

Kaźmierska K., 1996, Wywiad narracyjny - technika i pojęcia analityczne [w:] M. Czyżewski, A. Piotrowski, A. Rokuszewska-Pawełek (red.), Biografia a tożsamośćnarodowa, Łódź: Katedra Socjologii Kultury. Kowzan P. i in., 2016, Nie zostaje mi czasu na pracę naukowq; Warunki pracy osób ze stopniem doktora, zatrudnionych na polskich uczelniach, Gdańsk/Bydgoszcz/Warszawa.

Kraśniewski A., 2009, Kształcenie [w:] R.Z. Morawski (red.), Polskie szkolnictwo wyższe. Stan, uwarunkowania i perspektywy, Warszawa: WUW.

Malanowska K., 2013, Po co nam doktorat?, Dziennik Opinii, 2 stycznia.

Michalak D., 2013, Studia doktoranckie w Polsce - łatwo zacząć, trudniej skończyć. Komentarz po debacie „Proletariat wiedzy - doktoranci i doktorantki w polskim szkolnictwie wyższym", https:// noweotwarcie.org/2013/03/11/studia-doktoranckie-w-polsce-latwo-zaczac-trudniej-skonczyc/.

Narodowe Centrum Nauki, Wyjaśnienia dotyczące wynagrodzeń dla doktorantów, https://ncn.gov.pl/ aktualnosci/2015-06-17-wyjasnienia-wynagrodzenia-preludium.

Naczelna Izba Kontroli, 2015, Kształcenie na studiach doktoranckich. Informacja o wynikach kontroli, Warszawa: NIK.

Rosenthal G., 1993, Rekonstrukcja historii życia. Wybrane zasady generowania opowieści w wywiadach biograficzno-narracyjnych [w:] J. Włodarek, M. Ziółkowski (red.), Metoda biograficzna w socjologii. Warszawa-Poznań: PWN.

Schütze F., 1983, Biographieforschung und Narratives Interview, „Neue Praxis", No. 3.

Sobkowiak A. (red.), 2015, Studia doktoranckie i mobilność młodych naukowców, Warszawa: Rada Główna Nauki i Szkolnictwa Wyższego.

Standing G., 2014, Prekariat. Nowa niebezpieczna klasa, Warszawa: Wydawnictwo Naukowe PWN. Ustawa z dnia 27 lipca 2005 r. - Prawo o szkolnictwie wyższym (t.j. Dz. U. z 2017 r., poz. 2183 z późn. zm.). 